\title{
Eastern Promises Fulfilled: The Differential Impact of Marketing-Focused Short-Term Study Abroad Programs in India and Japan
}

\section{Zafar lqbal \\ DePaul University}

\begin{abstract}
:
This study compares two marketing-focused short-term study programs in Asia (India and Japan) and highlights reasons as to why students perceive that they learn more in one country than the other. Research to date has sparsely assessed the impact of study abroad programs on students' perceived growth. The existing literature has rarely focused on short-term study abroad programs while focusing mainly on undergraduate non-business students studying in Europe in long-term study abroad programs. Short-term study abroad programs (lasting less than eight weeks) are not considered rigorous enough and several doubts exist as to their effectiveness as a pedagogical technique. This paper uses survey methodology and a sample of 92 undergraduate and graduate business students who have completed a short-term study abroad program. The results show that students in these particular short-term study abroad programs perceive greater personal, professional, and inter-cultural growth than in a 10-week quarter-long course. Students' backgrounds could be a differential impact factor, but more research needs to be done. Marketing educators, when designing short-term study abroad programs, are encouraged to balance freedom and structure, and account for students' backgrounds.
\end{abstract}

\section{Introduction}

Marketing educators the world over strive to impart knowledge of key marketing concepts to students. Some of these concepts, such as customer orientation, consumer insights, consumer behavior, segmentation, empathic product design, and service co-creation, require students to learn how to metaphorically "walk a mile" in the shoes of consumers who are very different from themselves. In addition, marketing educators teach their students how to conduct complex environmental analyses that involve understanding trends in macroeconomics, regulations and laws, competitive actions, political perspectives, and specifically, the socio-cultural dynamics of markets and consumers (Kotler \& Keller, 2015). A driving assumption underlying teaching these concepts is that by understanding these topics well, students not only become better marketers, thus improving their employability (Diamond, Koernig, \& Iqbal, 2008), but also grow personally and better understand people who are very different from themselves (Koernig, 2007).

Developing a deep understanding of these concepts is not easy. Many educators believe that learning critical marketing concepts is best achieved through experiential learning (Frontczak \& Kelly, 2000). Students need to experience first-hand what textbooks and other readings describe as being the key concepts within the field of marketing. Experiential learning, as it pertains to marketing, can occur in a variety of formats (Frontczak \& Kelly, 2000). One specific form of 
experiential learning occurs when students participate in a short-term study abroad trip (Koernig, 2007). A short-term study abroad program is defined as an educational trip outside a student's country of education lasting less than eight weeks (Schau, Brasher, \& Fee, 2010).

Short-term study abroad programs are gaining in popularity, especially among business students. Of all study abroad trips taken by students studying in the United States in 2013-2014, short-term study abroad trips constituted $62.1 \%$ of the total number (Institute of International Education [IIE], 2015). In absolute terms, of the 304,467 U.S. students who studied abroad in 2013-2014, approximately 189,000 students studied abroad for less than eight weeks. Business students constituted $20 \%$ of all the U.S. students studying abroad (IIE, 2015). Factors driving this popularity include lower expenses, smaller time commitment, less time away from friends and family, lower anxiety, and better fit with academic schedule (Omachinski, 2013). With this increase in demand for short-term study abroad programs, it is not surprising that U.S. universities have increased the number of these programs offered (IIE, 2015). Many short-term study abroad models exist and each one of them can be considered to be a form of experiential learning. One of the models of short-term study abroad is the international study tour wherein students visit companies, along with a faculty member, in multiple cities in a foreign country (Sachau, Brasher, \& Fee, 2010). Research has shown that students completing a marketing course domestically, with local field visits, have a greater understanding of marketing (Van Doren \& Corrigan, 2008). In the international arena, however, the effectiveness of this pedagogical methodology has not been assessed.

Despite the increasing popularity of short-term study abroad programs, there remain persistent concerns about the academic quality of these programs (Gordon, 2010). While critical learning about cultures and markets through self-reflection remains an important learning objective, some research suggests that students end up learning more about themselves than about the cultures and markets that they are supposed to be studying (Gordon, 2010). Gullekson et al. (2011) show that while students do grow in their perceived intercultural competence after a short-term study abroad trip, the change does not help their perceived intercultural competence increase beyond that of a control group. Given that experiential learning is an extremely useful pedagogical technique to teach marketing concepts, and given that short-term study abroad, especially the international study tour, is a popular variant of experiential learning, it is surprising that very few studies exist that actually assess the outcomes of short-term study abroad programs. Notable exceptions do exist (Gullekson, Tucker, Garth Coombs, \& Wright, 2011; Omachinski, 2013; Zamastil-Vondrova, 2005), however, as the next section demonstrates, significant gaps still exist in the short-term study abroad literature.

\section{Gaps in the Study Abroad Literature}

Much has been written about study abroad programs and their benefits. Specifically, studies have assessed the impact of study abroad programs on three types of student learning outcomes. First, studies have assessed the impact on students' perceived personal growth. Studying abroad seems to improve students' perceptions of their self-efficacy (Cubillos \& Ilvento, 2012), their perceived selfconfidence (Forsey, Broomhall, \& Davis, 2011), and their perceived personal growth (Movassaghi, Unsal, \& Gocer, 2014). Second, studying abroad seems to improve students' perceived professional

\footnotetext{
${ }^{1}$ We use the term "perceived" rather than "actual" throughout the paper as it more accurately reflects constructs used in past research as well as those used in our paper. For more details on the distinction between "perceived" and "actual" learning, please refer to Bacon (2016).
} 
growth. Specifically, students seem to improve perceived cognitive skills (Mozelski, 2013), perceived language skills (Mozelski, 2013), and perceived workplace competencies (Gardner, Steglitz, \& Gross, 2009). Finally, studying abroad has been shown to improve students' perceived cultural growth. After studying abroad, students increased their perceived intercultural awareness, and lowered their perceived ethnocentrism and their perceived intercultural communication apprehension (Gullekson, Tucker, Garth Coombs, \& Wright, 2011). Further, business students participating in a study abroad program may have greater perceived intercultural proficiency, increased perceived openness to cultural diversity, and perceived themselves as being more globally minded than those students remaining in a traditional campus setting (Clarke III, Wright, Flaherty, \& McMillen, 2009).

Clearly, studying abroad has benefits for students in terms of their perceived personal, professional, and cultural growth. Notwithstanding the increase in study abroad literature, there are five knowledge gaps that still exist.

\section{Emphasis on Long-Term Study Abroad Programs}

The vast majority of empirical work on assessing the perceived outcomes of study abroad has been conducted with respect to long-term study abroad programs, which are defined as those that are at least a semester long (IIE, 2015). Most of the outcome assessment studies cited earlier addressed long-term study abroad. Notable exceptions exist, such as Gullekson et al. (2011), Omachinski (2013), and Cubillos and Ilvento (2013). However, excluding Gullekson et al. (2011), the latter two studies focused on engineering students and foreign language students, respectively. Gullekson et al. (2011) focused on students engaged in a different form of experiential learning, namely consulting work at the foreign location. Thus, very few studies have explicitly studied the perceived learning impact on business students of a short-term international study tour. Our study aims to address this gap.

\section{Emphasis on Undergraduate Students}

To date, most of the empirical work in the study abroad arena has focused on undergraduate students from different disciplines. Most independent institutions that provide nationwide statistics on study abroad focus entirely on counting and reporting on undergraduate students only (IIE, 2015). To an extent, this is not surprising as the majority of U.S. students studying abroad tend to be undergraduates. However, thanks to demands from accreditation organizations to make graduate business curricula more global and international, many business schools are now encouraging their MBA students to also participate in short-term study abroad programs (Oldford, 2010). MBA students tend to be older, more experienced, and perhaps more widely traveled than undergraduate students. Given the range of experience that MBA students already possess, it stands to reason that their learning from a short-term international study tour may be different than that of undergraduate students. Our study aims to study the differential impact of short-term international study tours on MBA and undergraduate business students.

\section{Emphasis Predominantly on European Study Abroad Programs}

Most of the existing empirical study abroad literature has assessed the perceived impact of programs in Europe, more specifically, Western Europe. Omachinski (2013) studied the perceived impact of short-term study abroad programs on engineering students studying in Germany. Gullekson et al. (2011) assessed the perceived impact of short-term programs on business students 
conducting consulting projects in mainly European locations (Denmark, France, Germany, Greece, Hungary, Italy, and Spain). They assessed the perceived impact of two additional non-European locations, namely Brazil and China, but by their own admission, the student sample sizes there were very small (11 and 8 respectively). Cubillos \& Ilvento (2013) studied foreign language students in France and Germany. Gardner et al. (2009) studied business students in Italy. Thus, as the above studies indicate, the impact on perceived learning of European study abroad locations has been assessed. In a way, this is not surprising given that of the top ten study abroad destinations for U.S. students, European countries accounted for six slots (IIE, 2015). However, in the past few years, Asian countries have also been featuring among the top destinations for U.S. students (IIE, 2015). Further, economies in Asia are rising rapidly and, at least based on the authors' observations as a consumer, it is likely that companies from Asia will fast become commonplace in the lives and careers of U.S. students. Given the increasing importance of Asian economies on the world stage and the fact that doing business in Asia is very different as compared to Western European countries, our study assesses the impact of studying abroad in Asia.

\section{Emphasis on Assessing Individual Study Abroad Programs}

Typically, most empirical assessments of study abroad programs measure the impact of a single program (Forsey, Broomhall, \& Davis, 2012; Gardner, Steglitz, \& Gross, 2009; Cubillos \& Ilvento, 2013; Omachinski, 2013). A few of these studies assess the impact of a single study abroad program on a set of student outcomes as compared to a control group of students who did not travel abroad (Clarke III, Wright, Flaherty, \& McMillen, 2009; Gullekson, Tucker, Garth Coombs, \& Wright, 2011). There exists a paucity of research comparing the outcomes of one short-term study abroad program in a country as compared to another similar program in a different country. Given that business students have a lot of choice when it comes to studying abroad (IIE, 2018) and possibly that most of them will study abroad just once, comparing the benefits of one program to another can help students make more informed choices. Particularly given that more students are choosing an Asian country as a study abroad destination and the fact that not much research exists on assessing study abroad programs in Asia, our study aims to compare the outcomes of participating in a short-term international study tour to Japan versus one in India. Currently, Japan is the tenth most sought-after destination and India is the twelfth most sought-after destination for U.S. students (IIE, 2015). Further, the year-over-year rates of growth of student participation in programs traveling to these countries are 4\% and 5\% respectively (IIE, 2015). Finally, in terms of GDP calculated according to the purchasing power parity method, India and Japan are the third and fourth largest economies in the world (IMF, 2016).

\section{Assumption that "One Size Fits All"}

The last gap in the study abroad literature that our study seeks to address relates to the strong assumption in all study abroad assessment research that individual student background makes no difference to perceived growth outcomes after a study-abroad trip. This is ironic considering that in the research on student motivations to study abroad, personality and other background variables have frequently been studied (Li, Olson, \& Frieze, 2013; Naffziger, Bott, \& Mueller, 2010; Movassaghi, Unsal, \& Gocer, 2014; Kavakas, 2013; Quraeshi, Luqmani, \& Veeck, 2012; Henthorne, Miller, \& Hudson, 2001; Goel, de Jong, \& Schnusenberg, 2010). Given that students' backgrounds and personalities are used to study why someone chooses to study abroad, it stands to reason that 
students' backgrounds will also determine what students get out of a study abroad program that they chose. Our study explicitly assesses the impact of a short-term international study tour on perceived learning outcomes for students based on their individual characteristics.

\section{Research Questions}

Based on the five gaps in the study abroad literature, our study contributes to the existing understanding of study abroad assessment by focusing on (i) short-term international business study tours, (ii) with undergraduate and graduate business students, (iii) traveling to two Asian countries, (iv) assessing three sets of perceived learning outcomes, (v) by comparing two Asian programs, and (vi) accounting for the different backgrounds that students bring to the program. Our three main research questions are as follows:

1. Do students traveling to India or Japan experience more perceived personal, professional, and cultural growth than during a 10 -week course in the United States?

2. Do students experience more perceived personal, professional, and cultural growth when participating in a short-term international study tour to India than in one that occurs in Japan?

3. When comparing a short-term international study tour to India versus one to Japan, what is the impact of bilingual skills, student status (graduate or undergraduate), and prior international travel experience on students' perceived personal, professional, and cultural growth?

The first research question addresses the concern that some researchers have regarding the perceived academic quality of short-term international study tours. The second research question compares two different short-term international study tours to the same continent to address the possibility that U.S. students perceive that they learn more in some programs than in others. The third question addresses the possibility that the reason why students perceive that they learn more in one short-term international study tour as compared to another is due to their differing backgrounds.

In terms of our variables of interest, perceived personal growth relates to the perceived level of confidence developed, developing a perceived sense of efficacy with respect to global issues, and feeling a perceived sense of responsibility towards global well-being (Cubillos \& Ilvento, 2013; Clarke III, Wright, Flaherty, \& McMillen, 2009; Hett, 1993). Perceived professional growth relates to the perceived level of learning that occurs, and the extent to which the course material is perceived as being applicable towards career goals (Diamond, Koernig, \& Iqbal, 2007; Gardner, Steglitz, \& Gross, 2009). Finally, perceived cultural growth relates to the extent to which students perceive themselves as accepting of cultural pluralism (Hett, 1993) and as more open to diversity (Pascarella et al, 1996), and increase their perceived intercultural communication skills, which is the ability to successfully communicate across cultures (Olson \& Kroeger, 2001).

\section{Describing the Two Short-term International Study Tours}

The design of both tours fit the description of a short-term study abroad tour. Both courses were offered to undergraduate and graduate business students at a large, private, and urban university in the United States. The same two professors, who used a team-teaching format, taught 
both courses with different students in each course. Both professors are marketing faculty at the business school of the university in question. At the undergraduate level, both courses counted towards an experiential learning requirement as well as a marketing elective course. For nonmarketing majors, both courses fulfilled the experiential learning requirement and an open business course elective. At the graduate level, both courses counted as either a marketing elective or an open business elective.

Table 1 highlights the similarities and key differences in the design and execution of both the India Business Seminar and the Japan Business Seminar. There are many similarities between the courses. Both had a strong emphasis on marketing as evidenced by the focus of both courses (emerging-market marketing and business strategy in the India seminar, and impact of national culture on marketing and business strategy in the Japan seminar), and the types of companies visited (advertising agencies, marketing research companies, luxury brands, retail, etc.). In addition, the people from both countries whom the students formally met at the companies had strong marketing backgrounds and were expert practitioners in their industries. Their titles reflected marketing backgrounds (e.g., CMO, VP Business Development, VP Brand Management, Owner, CEO, etc.).

An easy way to explain the course design of both courses is to think of them as having three phases: pre-trip, in-country, and post-trip. The pre-trip portion of both courses consisted of four inclass sessions, typically held on Friday nights for three hours. Thus, students in both courses had 12 contact hours with the faculty members and each other prior to leaving for the in-country portion. Each of the four sessions had a specific objective. The first session was used to explain the nature of the course, introduce the types of companies to be visited, share a broad itinerary with the students, and allow students to get to know each other and the faculty. Students selected their roommates in this session and each pair of roommates then chose a focal in-country company to research and present during the fourth session. The first session allowed students to develop familiarity with each other, the course, the country, and behavioral and deliverable expectations. The second session involved a deep dive into the respective country's culture with a robust discussion around one of the two books pre-assigned for the course. The purpose of the second session was to make students understand the focal country culture, particularly as it pertained to consumption and business practices, and how it differed from U.S. culture. The third session brought in business experts from country consulates, local companies with business interests in the focal country, and focal country companies with business interests in the US. Students were familiarized with differences in business practices, legal environments, cultural environments, and macroeconomic environments. These sessions were lively, with presentations followed by a question and answer period. The fourth pre-trip session involved the students making well-researched presentations on the companies they chose. Each pair of students had to make a 10- to 15-minute presentation on their understanding of the company's business model and its customer segments, prepare a dense one-page handout summarizing the company's details, which they provided to their classmates, and list 5 to 10 suggested questions to ask the company executives. Students were reminded to bring these handouts with them on the trip as a quick reference prior to visiting the company during the in-country portion. Students also turned in a one-page research proposal detailing the research question that they would answer after they returned to the US. The students were then provided with a detailed daily itinerary and explained emergency procedures on the trip. 
Table 1. Comparing the India \& the Japan short-term study abroad classes.

\begin{tabular}{|c|c|c|}
\hline Class Characteristic & India Business Seminar & Japan Business Seminar \\
\hline Maximum number of students & 20 & 20 \\
\hline Mix of students & Undergraduate \& Graduate & Undergraduate \& Graduate \\
\hline Credit hours & 4 & 4 \\
\hline Faculty & 2 Marketing professors & 2 Marketing professors \\
\hline Number of pre-trip meetings & 4 & 4 \\
\hline Readings & 2 Assigned books & 2 Assigned books \\
\hline Number of days in-country & 14 & 10 \\
\hline Number of cities visited & 5 & 5 \\
\hline Number of companies visited & 12 & 7 \\
\hline Types of companies visited & $\begin{array}{l}\text { Advertising, Marketing, Research, Retail, Info } \\
\text { Tech, Manufacturing, Services, Life Style, Start- } \\
\text { Up }\end{array}$ & $\begin{array}{l}\text { Advertising, Hospitality, } \\
\text { Manufacturing, Robotics, Luxury, } \\
\text { Start-Up }\end{array}$ \\
\hline Types of people met formally & CEOs, CMOs, VPs, Plant Heads, Entrepreneurs & CEOs, CMOs, VPs, Entrepreneurs \\
\hline Language used at meetings & English & Japanese with an interpreter \\
\hline $\begin{array}{l}\text { Extent to which typical day is } \\
\text { highly structured }\end{array}$ & Very High & Low to Medium \\
\hline $\begin{array}{l}\text { Freedom for students to explore } \\
\text { country during after-hours }\end{array}$ & Low to Medium & Very High \\
\hline $\begin{array}{l}\text { Language commonly used in } \\
\text { public spaces }\end{array}$ & English & $\begin{array}{l}\text { Japanese (English for very popular } \\
\text { places) }\end{array}$ \\
\hline Number of post-trip meetings & 1 & 1 \\
\hline Deliverables & $\begin{array}{l}\text { Pre-trip company presentation } \\
\text { Participation during trip } \\
\text { Post-trip } 20 \text { page research paper } \\
\text { Post-trip reflection presentation }\end{array}$ & $\begin{array}{l}\text { Pre-trip company presentation } \\
\text { Participation during trip } \\
\text { Post-trip } 20 \text { page research paper } \\
\text { Post-trip reflection presentation }\end{array}$ \\
\hline
\end{tabular}

The following descriptions are based on common themes that students have reported over the histories of these programs and that we use to give students a general idea of what they will encounter. They do lay a foundation of bias, but that is recognized, as the program faculty have to prepare the students with some country knowledge before departure. However, each person's experience can differ, as we are emphasizing the individual experience of each student, so the reporting stage is highly important.

When in the focal country, any single day consisted of one or two company visits. In Japan, public transportation was used to get to all the company visits whereas in India, the faculty members used a dedicated rented bus to transport students. A typical company visit in both countries involved a presentation on the company's marketing and business strategy by a senior executive, followed by a session of questions and answers, after which the students were given a guided plant or company tour that also included many questions and answers. A typical presentation session with questions and answers lasted about ninety minutes. A typical company visit lasted anywhere from two to four hours. In Japan, meetings were conducted with interpreters as very few of our students understood Japanese. In India, on the other hand, all the meetings were conducted in English as all the company 
executives spoke English. At the end of each company visit, faculty members led a 30-minute discussion to summarize the key items learned that day. Everyday, students had free time in late afternoon and chose to use that time to thoroughly explore what the city had to offer. This pattern repeated in each of the five cities in each country.

It was during the in-country portion that the two seminars started to differ, especially with respect to the free time that students were given. Japan is an extremely safe and developed country with a first-rate public transportation system. It boasts a world-class infrastructure that enables extremely precise planning, especially with respect to time. There are very few surprises in Japan when it comes to depending on public transportation. Students were easily able to navigate the city by themselves. Given that they had used public transportation earlier in the day to get to their company visits, in the evening, students exhibited no anxiety about exploring the cities by themselves. Furthermore, Japanese culture encourages a social nightlife (until very late at night) to support the business culture. Students frequently met and interacted with local business people in the evenings and given the social nature of this interaction, students learned a lot more about the business and consumption culture in Japan. Most nights they returned to the hotel well past midnight and were full of stories the next morning.

In India, on the other hand, public transportation is severely underdeveloped. It is extremely difficult to get from one place to another; hence the bus rented by faculty members to get everywhere. The lack of transportation infrastructure development in India forced faculty members to build in time buffers in order to get to company visits on time. As a comparison, in Japan, if one company was 35 miles away, the faculty members needed to plan for 45 minutes of travel time and there were no surprises. In India, if a company was 35 miles away, the faculty members needed to plan for 120 minutes of travel time just to ensure an on-time arrival. Naturally, the free time available in India at the end of the company visits was much reduced in comparison to that available in Japan. Coupled with that is the fact that most Indian cities start winding down after 10 p.m. and conditions become a little unsafe after that. Therefore, given the fact that students had very little familiarity with getting around in India, most evenings they ventured out within walking distance of the hotel and were usually back in the hotel by 10:30 p.m. This caused faculty members to organize planned trips with the students in the evenings to encourage them to venture further out. Overall, the free time available in India for students to explore after hours was either far reduced or was filled with more organized activities. Therefore, the India and Japan International Business Seminars differed with respect to degree of structure (more structure in India than Japan), language familiarity (language of communication is more familiar in India than Japan), and availability of free time to explore (less free time in India than in Japan).

After returning to the US, the students had approximately one month to write a detailed 20page research paper answering the research questions that they explored while in-country. At the last meeting, held a month after their return, students turned in their research papers and gave a presentation highlighting their reflections about what they learned on the trip about marketing and business in the focal countries. 


\section{Method}

In order to answer our three research questions, surveys were designed and administered to 143 students who had participated in either the India or the Japan International Business Seminar over the previous four years. Ninety-two completed surveys were returned, with 51 India Business Seminar participants and 41 Japan Business Seminar participants completing the survey. The aggregate response rate was $64.3 \%$. In order to test for recency bias, we compared the responses of students who had completed the course within the past two years to the group that had completed the seminar in the preceding two years. No significant differences on any variables of interest were found. Measures of all dependent variables are provided in the Appendix.

\section{Measures of Perceived Personal Growth}

We studied three constructs that relate to perceived personal growth following the international short-term study tour. The three constructs studied were perceived level of confidence, perceived level of efficacy, and perceived sense of responsibility. Past studies have shown that these three constructs relate to perceived personal growth (Clarke III, Wright, Flaherty, \& McMillen, 2009). Perceived level of confidence was measured by a single-item 1 to 7 Likert scale that asked participants to rate the extent to which they believed that the study tour increased their level of confidence as compared to a traditional quarter-long course. Perceived level of efficacy was measured using a 5-item 1 to 7 Likert scale developed by Hett (1993) that asked students to rate their level of agreement with items that assessed the extent to which students believed that they could do something about global issues after participating on the study tour. This scale has been used extensively and has demonstrated consistent reliability in a number of studies (Hett, 1993; Clarke III, Wright, Flaherty, \& McMillen, 2009; Gillian, 1996). Finally, perceived sense of responsibility was measured using a 7-item 1 to 7 Likert scale (Hett, 1993) that asked students to rate their level of agreement with items that assessed the extent to which students believed that they had an obligation to respond to global issues. Again, this scale has been used extensively and has demonstrated good reliability (Hett, 1993; Clarke III, Wright, Flaherty, \& McMillen, 2009; Gillian, 1996).

\section{Measures of Perceived Professional Growth}

The key constructs used that relate to perceived professional growth following the international short-term study tour were perceived level of learning and perceived applicability to career goals. Perceived level of learning was measured using a single-item 1 to 7 Likert scale that asked participants to rate the extent to which they believed that they learned more on the study tour than in a traditional quarter-long course. Perceived applicability to career goals was measured using a single-item 1 to 7 Likert scale that asked respondents to rate the extent to which they believed that the study tour was directly applicable to their career goals.

\section{Measures of Perceived Cultural Growth}

The three constructs that relate to perceived cultural growth following the international shortterm study tour were perceived acceptance of cultural pluralism, perceived openness to diversity, and perceived intercultural communication ability. Perceived acceptance of cultural pluralism was measured using an 8-item 1 to 7 Likert scale that assessed respondents' level of agreement with statements about the extent to which they could learn from other people's perspectives. This scale has been used in a variety of contexts and has demonstrated good reliability (Hett, 1993; Clarke III, 
Wright, Flaherty, \& McMillen, 2009; Gillian, 1996). Perceived openness to diversity was measured using Pascarella et al.'s (1996) 8-item scale. This scale has been tested in multiple contexts and has exhibited strong reliability (Ismail, Morgan, \& Hayes, 2006; Pike, 2002). Finally, perceived intercultural communication ability was measured using an 11-item scale developed by Olson \& Kroeger (2001) that assessed the extent to which students believe that by participating on the study tour, their ability to communicate with people different from them had increased. (Inter-variable correlations and scale reliabilities are presented in Table 2.)

The first research question asked whether students studying abroad for a marketing elective course in either India or Japan perceive that they experience more growth than when they take a regular 10-week quarter-long course. To test this, we compared the means of each variable of interest within each country with the neutral option value of the 7-point Likert scale. If a student selected the neutral value, it implied that he/she perceived that the specific study tour enabled them to grow the same amount as taking a regular quarter-long course in the US. We used t-tests to ascertain whether they were any significant differences in growth. For a single-item scale, the neutral value used was 4 . For an 8 -item scale, the neutral value used was $8 \times 4=32$ and so on.

The second research question asked which international study tour impacted the students more. To assess this, we compared the means of all variables of interest for students taking the India Business Seminar with the means of the students taking the Japan Business Seminar.

To answer the third research question, we conducted three sequential mean comparisons on the variables of interest. First, we divided the sample into two groups: students who spoke more than one language (bilingual) and students who spoke only one language (non bilingual). Within the bilingual group, we compared students who traveled to India to those who traveled to Japan. We did the same for the non bilingual group.

Table 2. Correlations and scale reliabilities (on diagonal).

\begin{tabular}{|c|c|c|c|c|c|c|c|c|}
\hline & $\begin{array}{l}\text { Self } \\
\text { Confidence }\end{array}$ & Efficacy & $\begin{array}{l}\text { Sense of } \\
\text { Respon- } \\
\text { sibility }\end{array}$ & $\begin{array}{l}\text { Level of } \\
\text { Learning }\end{array}$ & $\begin{array}{l}\text { Applicability } \\
\text { to Career } \\
\text { Goals }\end{array}$ & $\begin{array}{l}\text { Cultural } \\
\text { Pluralism }\end{array}$ & $\begin{array}{l}\text { Openness } \\
\text { to } \\
\text { Diversity }\end{array}$ & $\begin{array}{l}\text { Intercultural } \\
\text { Communication }\end{array}$ \\
\hline Self Confidence & Single item & & & & & & & \\
\hline Efficacy & $0.38^{* * * *}$ & 0.77 & & & & & & \\
\hline $\begin{array}{l}\text { Sense of } \\
\text { Responsibility }\end{array}$ & $0.33^{* * * *}$ & $0.60^{\text {**** }}$ & 0.85 & & & & & \\
\hline $\begin{array}{l}\text { Level of } \\
\text { Learning }\end{array}$ & $0.68^{* * * *}$ & $0.42^{* * * *}$ & $0.40^{* * * *}$ & $\begin{array}{l}\text { Single } \\
\text { item }\end{array}$ & & & & \\
\hline $\begin{array}{l}\text { Applicability to } \\
\text { Career Goals }\end{array}$ & $0.52^{* * * *}$ & 0.19 & 0.21 & $0.64^{* * * *}$ & Single item & & & \\
\hline $\begin{array}{l}\text { Cultural } \\
\text { Pluralism }\end{array}$ & $0.40^{* * * *}$ & $0.62^{* * * *}$ & $0.58^{* * * *}$ & $0.51^{* * * *}$ & $0.26^{* *}$ & 0.73 & & \\
\hline $\begin{array}{l}\text { Openness to } \\
\text { Diversity }\end{array}$ & $0.26^{* *}$ & $0.46^{* * * *}$ & $0.41^{* * * *}$ & $0.33^{* * *}$ & 0.20 & $0.48^{* * * *}$ & 0.84 & \\
\hline $\begin{array}{l}\text { Intercultural } \\
\text { Communication }\end{array}$ & $0.29^{* * * *}$ & $0.47^{* * * *}$ & 0.20 & $0.24^{* *}$ & 0.11 & $0.45^{* * * *}$ & $0.50^{* * * *}$ & 0.79 \\
\hline
\end{tabular}


To continue answering the third research question, we again divided the original sample into two groups: students who participated in one of the two short-term international study tours as undergraduates and those who did so as graduate students. Within the undergraduate group, we compared students who traveled to India versus those who traveled to Japan. We did the same for the graduate student group.

Finally, we again divided the original sample into two groups: students who participated in one of the two short-term international study tours with less than eight prior international trips (less experienced) and those who did so with eight or more prior international trips (more experienced). We used a rough median split on prior travel experience to divide the sample. Within the less experienced travel group, we compared students who traveled to India versus those who traveled to Japan. We did the same for the more experienced travel student group.

\section{Results}

The gender breakdown among the respondents was 53\% female and $47 \%$ male. In terms of student status at the time the study tour was taken, $48 \%$ of the respondents were undergraduate and $52 \%$ were graduate students. In terms of age breakdown at the time the study tour was taken, $36 \%$ were between the ages of 20 to 22, 11\% were between the ages of 23 to 25, 32\% were between the ages of 26 to $30,11 \%$ were between the ages of 30 to 35, and the remaining were older than 35 . With respect to previous international travel experience, $4 \%$ had traveled abroad once, 13\% had traveled abroad 2 to 3 times, 29\% had traveled abroad 4 to 7 times, 19\% had traveled abroad 8 to 10 times, and 35\% had traveled abroad more than 10 times.

In this section we report the results of our analyses; the results are discussed in the subsequent section. Table 3 provides the results comparing perceived growth after taking the India Business Seminar as compared to taking a 10-week quarter-long course in the US, as well as the results comparing growth after taking the Japan Business Seminar as compared to taking a quarter-long course in the US. Students, irrespective of whether they traveled to India or Japan, believe that they experienced more personal, professional, and cultural growth on the international study tour than they did when taking a regular quarter-long course in the US. The results were highly significant $(\mathrm{p}<$ 0.01) for all variables of interest in both India and Japan.

Table 3. Comparing short-term study abroad outcomes with a regular 10-week course.

\begin{tabular}{|c|c|c|c|c|c|}
\hline \multirow[t]{2}{*}{ Outcomes } & \multirow{2}{*}{$\begin{array}{l}\text { Neutral Value } \\
\text { Used }\end{array}$} & India $(\mathbf{n}=\mathbf{5 1})$ & $\mathbf{t}$ & Japan $(n=41)$ & $\mathbf{t}$ \\
\hline & & Means (S.D) & & Means (S.D) & \\
\hline \multicolumn{6}{|l|}{ Personal Growth } \\
\hline 1. Self Confidence & 4 & $5.65(1.34)$ & $8.78^{* * * *}$ & $6.07(1.03)$ & $12.84^{* * * *}$ \\
\hline 2. Efficacy & 20 & $25.85(4.22)$ & $9.60^{* * * *}$ & $27.13(5.74)$ & $7.66^{* * * *}$ \\
\hline 3. Sense of Responsibility & 28 & $35.63(6.65)$ & $7.78^{* * * *}$ & $36.40(7.42)$ & $6.89^{* * * *}$ \\
\hline \multicolumn{6}{|l|}{ Professional Growth } \\
\hline 1. Level of Learning & 4 & $5.53(1.51)$ & $7.21^{* * * *}$ & $6.02(1.25)$ & $10.33^{* * *}$ \\
\hline 2. Applicability to Career Goals & 4 & $5.39(1.17)$ & $8.51^{* * * *}$ & $5.66(1.15)$ & $9.21^{* * * *}$ \\
\hline
\end{tabular}




\begin{tabular}{|c|l|l|l|l|l|}
\hline Intercultural Growth & & & & & \\
\hline 1. Cultural Pluralism & 32 & $49.23(4.14)$ & $28.82^{* * *}$ & $49.45(4.60)$ & $23.13^{* * *}$ \\
\hline 2. Openness to Diversity & 32 & $49.47(4.30)$ & $27.86^{* * *}$ & $49.34(5.10)$ & $20.94^{* * *}$ \\
\hline 3. Intercultural Communication & 44 & 59.72 & $13.33^{* * *}$ & $59.53(10.44)$ & $9.16^{* * *}$ \\
\hline
\end{tabular}

*** p-value significant at the 0.01 level (2-tailed)

Table 4 shows the results of the comparison between the India and the Japan international study tours. With respect to perceived personal growth, students traveling to Japan marginally perceived that they gained more self-confidence than students traveling to India. There were no observed differences with respect to perceived efficacy and perceived sense of responsibility. With respect to perceived professional growth, students who traveled to Japan reported a marginally higher level of perceived learning compared to students traveling to India. No difference was reported with respect to perceived applicability to career goals. Finally, with respect to perceived cultural growth, no differences were found between students traveling to Japan and those traveling to India with respect to perceived cultural pluralism, perceived openness to diversity, and perceived intercultural communication. These results suggest that both the India Business Seminar and the Japan Business Seminar provide comparable levels of perceived personal, professional, and cultural growth. We discuss these results in the Discussion section.

Table 4. Comparing short-term study abroad outcomes: India vs. Japan.

\begin{tabular}{|c|l|l|l|}
\hline \multirow{2}{*}{ Outcomes } & India (n= 51) & Japan (n= 41) & t \\
\cline { 2 - 4 } & Means (S.D) & Means (S.D) & \\
\hline Personal Growth & & & \\
\hline 1. Self Confidence & $5.65(1.34)$ & $6.07(1.03)$ & $-1.68^{*}$ \\
\hline 2. Efficacy & $25.85(4.22)$ & $27.13(5.74)$ & -1.19 \\
\hline 3. Sense of Responsibility & $35.63(6.65)$ & $36.40(7.42)$ & -.49 \\
\hline Professional Growth & & & \\
\hline 1. Level of Learning & $5.53(1.51)$ & $6.02(1.25)$ & $-1.68^{*}$ \\
\hline 2.Applicability to Career Goals & $5.39(1.17)$ & $5.66(1.15)$ & .28 \\
\hline Intercultural Growth & & & \\
\hline 1. Cultural Pluralism & $49.23(4.14)$ & $49.45(4.60)$ & -.24 \\
\hline 2. Openness to Diversity & $49.47(4.30)$ & $49.34(5.10)$ & .12 \\
\hline 3. Intercultural Communication & 59.72 & $59.53(10.44)$ & .99 \\
\hline
\end{tabular}

*p-value significant at the 0.1 level (2-tailed)

Table 5 highlights the results of the comparisons between bilingual and non bilingual students traveling to India versus Japan. Within the bilingual group, we found that students who traveled to Japan, compared to those who traveled to India, had significantly higher levels of perceived personal growth (perceived self-confidence, perceived efficacy, and perceived responsibility), perceived professional growth (perceived level of learning and perceived applicability to career goals), and 
perceived cultural growth (perceived cultural pluralism and perceived openness to diversity). In terms of perceived intercultural communication, no significant differences were found. When we looked at non bilingual students, an interesting reversal of results occurred. Students who traveled to India, as compared to those who traveled to Japan, reported somewhat higher levels of perceived personal growth (perceived sense of responsibility) and perceived cultural growth (perceived cultural pluralism and perceived openness to diversity). No significant differences were found in perceived professional growth, two variables assessing perceived personal growth (perceived self-confidence and perceived efficacy), and one variable assessing perceived cultural growth (perceived intercultural communication).

Table 5. Comparing short-term study abroad outcomes based on language skills: India vs. Japan.

\begin{tabular}{|c|c|c|c|c|c|c|}
\hline \multirow{3}{*}{ Outcomes } & \multicolumn{2}{|l|}{$\begin{array}{l}\text { Bilingual } \\
\text { Students }\end{array}$} & \multirow[b]{2}{*}{$\mathrm{t}$} & \multicolumn{2}{|c|}{ Non-Bilingual Students } & \multirow[b]{2}{*}{$\mathrm{t}$} \\
\hline & $\begin{array}{l}\text { India } \\
(n=20)\end{array}$ & $\begin{array}{l}\text { Japan } \\
(\mathrm{n}=22)\end{array}$ & & $\begin{array}{l}\text { India } \\
(n=31)\end{array}$ & Japan $(n=19)$ & \\
\hline & $\begin{array}{l}\text { Means } \\
\text { (S.D) }\end{array}$ & $\begin{array}{l}\text { Means } \\
(\text { S.D })\end{array}$ & & $\begin{array}{l}\text { Means } \\
\text { (S.D) }\end{array}$ & Means (S.D) & \\
\hline \multicolumn{7}{|l|}{ Personal Growth } \\
\hline 1. Self Confidence & $\begin{array}{l}5.05 \\
(1.39)\end{array}$ & $\begin{array}{l}6.14 \\
(1.08)\end{array}$ & $-2.83^{* * *}$ & $\begin{array}{l}6.03 \\
(1.17)\end{array}$ & $\begin{array}{l}6.00 \\
(1.0)\end{array}$ & 0.1 \\
\hline 2. Efficacy & $\begin{array}{l}25.31 \\
(3.46)\end{array}$ & $\begin{array}{l}29.04 \\
(5.44)\end{array}$ & $-2.55^{* *}$ & $\begin{array}{l}26.2 \\
(4.68)\end{array}$ & $\begin{array}{l}24.76 \\
(5.32)\end{array}$ & 0.96 \\
\hline 3. Sense of Responsibility & $\begin{array}{l}32.72 \\
(7.82)\end{array}$ & $\begin{array}{l}38.8 \\
(7.25)\end{array}$ & $-2.48^{* *}$ & $\begin{array}{l}37.5 \\
(5.08)\end{array}$ & $\begin{array}{l}33.58 \\
(6.78)\end{array}$ & $2.20^{* * * *}$ \\
\hline \multicolumn{7}{|l|}{ Professional Growth } \\
\hline 1. Level of Learning & $\begin{array}{l}4.8 \\
(1.58)\end{array}$ & $\begin{array}{l}6.23 \\
(0.98)\end{array}$ & $-3.57^{* * * *}$ & $\begin{array}{l}6.00 \\
(1.29)\end{array}$ & $\begin{array}{l}5.79 \\
(1.51)\end{array}$ & 0.52 \\
\hline 2. Applicability to Career Goals & $\begin{array}{l}4.85 \\
(1.27)\end{array}$ & $\begin{array}{l}5.77 \\
(1.06)\end{array}$ & $-2.56^{* *}$ & $\begin{array}{l}5.74 \\
(0.96)\end{array}$ & $\begin{array}{l}5.53 \\
(1.26)\end{array}$ & 0.68 \\
\hline \multicolumn{7}{|l|}{ Intercultural Growth } \\
\hline 1. Cultural Pluralism & $\begin{array}{l}48.53 \\
(3.98)\end{array}$ & $\begin{array}{l}51.37 \\
(3.83)\end{array}$ & $-2.24^{* *}$ & $\begin{array}{l}49.68 \\
(4.25)\end{array}$ & $\begin{array}{l}47.44 \\
(4.55)\end{array}$ & $1.71^{*}$ \\
\hline 2. Openness to Diversity & $\begin{array}{l}48.16 \\
(4.03)\end{array}$ & $\begin{array}{l}51.7 \\
(3.24)\end{array}$ & $-3.03^{* * *}$ & $\begin{array}{l}50.35 \\
(4.31)\end{array}$ & $\begin{array}{l}46.72 \\
(5.58)\end{array}$ & $2.48^{* * *}$ \\
\hline 3. Intercultural Communication & $\begin{array}{l}61.53 \\
(7.53)\end{array}$ & $\begin{array}{l}62.35 \\
(9.73)\end{array}$ & -.29 & $\begin{array}{l}58.5 \\
(8.35)\end{array}$ & $\begin{array}{l}56.38 \\
(10.57)\end{array}$ & 0.75 \\
\hline
\end{tabular}

*p-value significant at the 0.1 level (2-tailed); ** p-value significant at the 0.05 level (2-tailed); *** p-value significant at the 0.01 level

Table 6 highlights the results comparing undergraduate and graduate students traveling to India versus Japan. Overall, the pattern of results seems to suggest no major differences in perceived growth in either group. There are two exceptions to this pattern. Undergraduate students traveling to Japan reported marginally higher perceived levels of self-confidence as well as higher perceived levels of learning compared to undergraduate students traveling to India. 
Table 6. Comparing short-term study abroad outcomes based on student status: India vs. Japan.

\begin{tabular}{|c|c|c|c|c|c|c|}
\hline \multirow{3}{*}{ Outcomes } & \multicolumn{2}{|c|}{ Undergraduate Students } & \multirow[b]{2}{*}{$\mathrm{t}$} & \multicolumn{2}{|l|}{$\begin{array}{l}\text { Graduate } \\
\text { Students }\end{array}$} & \multirow[b]{2}{*}{$\mathrm{t}$} \\
\hline & $\begin{array}{l}\text { India } \\
(\mathrm{n}=20)\end{array}$ & $\begin{array}{l}\text { Japan } \\
(\mathrm{n}=21)\end{array}$ & & $\begin{array}{l}\text { India } \\
(n=31)\end{array}$ & $\begin{array}{l}\text { Japan } \\
(\mathrm{n}=20)\end{array}$ & \\
\hline & $\begin{array}{l}\text { Means } \\
\text { (S.D) }\end{array}$ & $\begin{array}{l}\text { Means } \\
\text { (S.D) }\end{array}$ & & $\begin{array}{l}\text { Means } \\
\text { (S.D) }\end{array}$ & $\begin{array}{l}\text { Means } \\
\text { (S.D) }\end{array}$ & \\
\hline \multicolumn{7}{|l|}{ Personal Growth } \\
\hline 1. Self Confidence & $\begin{array}{l}5.65 \\
(1.23)\end{array}$ & $\begin{array}{l}6.24 \\
(0.89)\end{array}$ & $-1.76^{*}$ & $\begin{array}{l}5.65 \\
(1.43)\end{array}$ & $\begin{array}{l}5.9 \\
(1.16)\end{array}$ & -0.67 \\
\hline 2. Efficacy & $\begin{array}{l}25.75 \\
(4.29)\end{array}$ & $\begin{array}{l}26.11 \\
(6.16)\end{array}$ & -0.21 & $\begin{array}{l}25.93 \\
(4.25)\end{array}$ & $\begin{array}{l}28.05 \\
(5.32)\end{array}$ & -1.53 \\
\hline 3. Sense of Responsibility & $\begin{array}{l}36.84 \\
(4.93)\end{array}$ & $\begin{array}{l}35.47 \\
(7.03)\end{array}$ & 0.68 & $\begin{array}{l}34.78 \\
(7.6)\end{array}$ & $\begin{array}{l}37.20 \\
(7.84)\end{array}$ & -1.07 \\
\hline \multicolumn{7}{|l|}{ Professional Growth } \\
\hline 1. Level of Learning & $\begin{array}{l}5.40 \\
(1.46)\end{array}$ & $\begin{array}{l}6.29 \\
(1.19)\end{array}$ & $-2.13^{* *}$ & $\begin{array}{l}5.61 \\
(1.56)\end{array}$ & $\begin{array}{l}5.75 \\
(1.29)\end{array}$ & -0.33 \\
\hline 2. Applicability to Career Goals & $\begin{array}{l}5.40 \\
(0.94)\end{array}$ & $\begin{array}{l}5.76 \\
(1.09)\end{array}$ & -1.13 & $\begin{array}{l}5.39 \\
(1.31)\end{array}$ & $\begin{array}{l}5.55 \\
(1.23)\end{array}$ & -0.44 \\
\hline \multicolumn{7}{|l|}{ Intercultural Growth } \\
\hline 1. Cultural Pluralism & $\begin{array}{l}48.65 \\
(4.00)\end{array}$ & $\begin{array}{l}49.17 \\
(3.81)\end{array}$ & -0.41 & $\begin{array}{l}49.64 \\
(4.26)\end{array}$ & $\begin{array}{l}49.74 \\
(5.32)\end{array}$ & -0.07 \\
\hline 2. Openness to Diversity & $\begin{array}{l}50.74 \\
(3.98)\end{array}$ & $\begin{array}{l}49.47 \\
(5.17)\end{array}$ & 0.84 & $\begin{array}{l}48.61 \\
(4.36)\end{array}$ & $\begin{array}{l}49.21 \\
(5.18)\end{array}$ & -0.43 \\
\hline 3. Intercultural Communication & $\begin{array}{l}59.58 \\
(8.15)\end{array}$ & $\begin{array}{l}59.78 \\
(9.39)\end{array}$ & -0.07 & $\begin{array}{l}59.82 \\
(8.19)\end{array}$ & $\begin{array}{l}59.26 \\
(11.65)\end{array}$ & 0.19 \\
\hline
\end{tabular}

*p-value significant at the 0.1 level (2-tailed); ** p-value significant at the 0.05 level (2-tailed); $* * *$ p-value significant at the 0.01 level

Table 7 highlights the results comparing students with less international travel experience and with more international travel experience, traveling to India versus Japan. Within the lessexperienced group, no differences were observed in either perceived personal or perceived professional growth. In terms of perceived intercultural growth, less-experienced students traveling to India showed higher perceived openness to diversity and higher perceived intercultural communication. No differences were observed with respect to perceived cultural pluralism. For students with greater prior travel experience, traveling to Japan, as opposed to traveling to India, resulted in higher perceived personal growth (perceived self-confidence and perceived efficacy), higher perceived professional growth (perceived level of learning and perceived applicability to career goals), and perceived higher levels of intercultural growth (perceived openness to diversity and perceived intercultural communication). No differences were observed with respect to perceived sense of responsibility and perceived cultural pluralism. 
Table 7. Comparing short-term study abroad outcomes based on travel experience: India vs. Japan.

\begin{tabular}{|c|c|c|c|c|c|c|}
\hline \multirow{3}{*}{ Outcomes } & \multicolumn{2}{|c|}{$\begin{array}{l}\text { Less Experienced } \\
\text { International } \\
\text { Travelers }\end{array}$} & \multirow[b]{2}{*}{$\mathrm{t}$} & \multicolumn{2}{|c|}{$\begin{array}{l}\text { More Experienced } \\
\text { International Travelers }\end{array}$} & \multirow{2}{*}{ t } \\
\hline & $\begin{array}{l}\text { India } \\
(\mathrm{n}=20)\end{array}$ & $\begin{array}{l}\text { Japan } \\
(\mathrm{n}=22)\end{array}$ & & $\begin{array}{l}\text { India } \\
(\mathrm{n}=31)\end{array}$ & $\begin{array}{l}\text { Japan } \\
(\mathrm{n}=19)\end{array}$ & \\
\hline & $\begin{array}{l}\text { Means } \\
\text { (S.D) }\end{array}$ & $\begin{array}{l}\text { Means } \\
\text { (S.D) }\end{array}$ & & $\begin{array}{l}\text { Means } \\
\text { (S.D) }\end{array}$ & $\begin{array}{l}\text { Means } \\
\text { (S.D) }\end{array}$ & \\
\hline \multicolumn{7}{|l|}{ Personal Growth } \\
\hline 1. Self Confidence & $\begin{array}{l}5.70 \\
(1.13)\end{array}$ & $\begin{array}{l}5.91 \\
(1.02)\end{array}$ & -0.63 & $\begin{array}{l}5.61 \\
(1.48)\end{array}$ & $\begin{array}{l}6.26 \\
(1.05)\end{array}$ & $-1.68^{*}$ \\
\hline 2. Efficacy & $\begin{array}{l}24.89 \\
(4.76)\end{array}$ & $\begin{array}{l}25.10 \\
(5.63)\end{array}$ & -0.12 & $\begin{array}{l}26.48 \\
(3.78)\end{array}$ & $\begin{array}{l}29.39 \\
(5.09)\end{array}$ & $-2.24^{* *}$ \\
\hline 3. Sense of Responsibility & $\begin{array}{l}34.89 \\
(6.13) \\
\end{array}$ & $\begin{array}{l}34.85 \\
(7.49) \\
\end{array}$ & 0.02 & $\begin{array}{l}36.11 \\
(7.02) \\
\end{array}$ & $\begin{array}{l}38.23 \\
(7.13) \\
\end{array}$ & -0.98 \\
\hline \multicolumn{7}{|l|}{ Professional Growth } \\
\hline 1. Level of Learning & $\begin{array}{l}5.6 \\
(1.35) \\
\end{array}$ & $\begin{array}{l}5.82 \\
(1.40) \\
\end{array}$ & -0.51 & $\begin{array}{l}5.48 \\
(1.63) \\
\end{array}$ & $\begin{array}{l}6.26 \\
(1.05) \\
\end{array}$ & $-1.86^{*}$ \\
\hline 2. Applicability to Career Goals & $\begin{array}{l}5.65 \\
(1.09)\end{array}$ & $\begin{array}{l}5.45 \\
(1.14)\end{array}$ & 0.67 & $\begin{array}{l}5.23 \\
(1.20)\end{array}$ & $\begin{array}{l}5.89 \\
(1.15)\end{array}$ & $-1.94^{*}$ \\
\hline \multicolumn{7}{|l|}{ Intercultural Growth } \\
\hline 1. Cultural Pluralism & $\begin{array}{l}49.00 \\
(4.00)\end{array}$ & $\begin{array}{l}48.57 \\
(4.03)\end{array}$ & 0.34 & $\begin{array}{l}49.38 \\
(4.30)\end{array}$ & $\begin{array}{l}50.62 \\
(5.14)\end{array}$ & -0.87 \\
\hline 2. Openness to Diversity & $\begin{array}{l}49.67 \\
(4.34)\end{array}$ & $\begin{array}{l}47.05 \\
(4.76)\end{array}$ & $1.76^{*}$ & $\begin{array}{l}49.34 \\
(4.34)\end{array}$ & $\begin{array}{l}51.89 \\
(4.28)\end{array}$ & $-1.96^{*}$ \\
\hline 3. Intercultural Communication & $\begin{array}{l}60.05 \\
(7.73)\end{array}$ & $\begin{array}{l}54.85 \\
(10.05)\end{array}$ & $1.77^{*}$ & $\begin{array}{l}59.52 \\
(8.43)\end{array}$ & $\begin{array}{l}64.72 \\
(8.37)\end{array}$ & $-2.06^{* *}$ \\
\hline
\end{tabular}

*p-value significant at the 0.1 level (2-tailed); ** p-value significant at the 0.05 level (2-tailed); *** p-value significant at the 0.01 level

\section{Discussion}

When analyzing the results reported in the previous section, six clear themes emerged. First, our study shows that using an experiential format, specifically a short-term international study tour, can enhance these students' perceived personal, professional, and intercultural growth. Previous studies have demonstrated the impact of study abroad on a select set of outcomes, but our study, while accounting for the major gaps in the literature, shows these students perceived that they learned more when they got to experience their learning in an international setting. Given the wide misconceptions that many marketing educators have regarding the value of short-term study abroad programs, we show that well-designed study abroad programs, with strong academic content contextualized through in-country company visits, can enhance student perceptions of learning. We also compared dependent variable means of students who took the course within the past two years with those who took the course more than two years ago and found no significant difference. We can also tentatively conclude that student perceptions of learning persist over time.

Second, the results (Table 3) suggest that a marketing elective, offered as a short-term study abroad tour, permitted these students to perceptually grow more than a regular 10-week quarter-long marketing course. It didn't matter which of the two Asian countries students traveled to-both helped enhance students' perceptions of personal, professional, and inter-cultural growth. Our 
results confirm, within a short-term study abroad format, what many researchers have shown to be true with respect to longer-term study abroad programs. Taking a marketing course, formatted as an international short-term study tour, impacts students' perceptions positively.

Third, as Table 4 demonstrates, at the aggregate level, the Japan International Business Seminar impacted students' perceptions of growth marginally more than the India Business Seminar, specifically with respect to increased perceived self-confidence and increased perceived level of learning. To explain these results, it is important to look at items 12 through 15 in Table 1 . In the Japan International Business Seminar, students are given a lot more freedom to explore the country than they are given in the India Business Seminar. While the reason for this is inherently due to the infrastructure in both countries, we saw nevertheless that giving students more freedom to explore helps them gain more perceived self-confidence and enhance their perceived learning. This has been alluded to by Koernig (2007) and anecdotally demonstrated by Kaplin (2013) and Omachinski (2013). Our results call for a more balanced approach in designing daily activities during a shortterm study abroad tour. It is interesting to note that students perceived that they learned more and gained more perceived self-confidence in Japan, despite the language barrier.

At the aggregate level, giving students more freedom seems to help overcome anxieties caused by possible language barriers. In addition, it is possible that the psychic distance when comparing the United States of America to both India and Japan is very similar (Dow and Karunaratna, 2006). Thus, it may have been that while both the India and the Japan International Business Seminars are very different from a similar experiential learning opportunity in the United States, participants from both seminars perceived the psychic difference between their focal country and the United States to be very similar thus negating any differences in comparisons. Future research is needed to better answer which of the above two possibilities explains the lack of differences in the results.

Fourth, our results show that the students with varying language abilities perceived that they gain from differently formatted international study tours. Students with fluency in more than one language, even if the additional languages are not native to the country being visited, ended up experiencing more perceived growth in a country that had an unfamiliar language, i.e., Japan. Perhaps being bilingual or multilingual lessened these students' fear of language differences. For non-bilingual students, perceived growth was experienced in an environment where language barriers do not occur, i.e., India. This finding has targeting implications that will be elaborated on in the next section.

Fifth, for undergraduate students, traveling to Japan helped them experience more perceived learning and helped them gain more perceived confidence than traveling to India. Again, this possibly ties back to the freedom offered to students in Japan versus that in India. Undergraduate students tend to be mostly younger than graduate students, and for younger adults, freedom to explore and find their comfort zone seems to facilitate perceived self-confidence and perceived learning. Interestingly, graduate students don't seem to be affected too much by the availability of this freedom suggesting perhaps that older students will learn no matter what the environment. Many graduate students are self-financed and tend to be more focused on their education irrespective of their environment. 
Finally, level of previous international travel experience does seem to impact the extent to which these students perceived that they experienced growth on an international study tour. For less-experienced international travelers, perceived cultural growth tended to occur more in India than in Japan. This suggests that a structured learning environment in which daily activities are well planned could assist in perceived cultural growth. It also appears that for less-experienced travelers, studying in a country whose language is familiar also assisted in perceived cultural growth. This implies that previous recommendations to balance daily structure and freedom may not apply as much to less experienced travelers. In the case of more experienced travelers, Japan seems to be more conducive to their overall growth in all three areas. Given that these travelers were more experienced implies that they perceived more overall growth when there was more daily freedom despite the language barriers. Experienced travelers seemed capable of navigating complex and unfamiliar environments that seemed to assist in their overall perceived growth.

\section{Implications}

Our study has several implications for marketing educators. First, as much as possible, marketing educators should encourage experiential learning in the classes that they teach. While we specifically studied experiential learning in the context of an international short-term study abroad tour, our findings are consistent with the marketing education literature that encourages more experiential learning.

Second, short-term study abroad courses that teach marketing seem to be superior to teaching a regular quarter-long course when it comes to student perceptions of learning. Given the professional and intercultural concepts, such as customer orientation, consumer insights, consumer behavior, segmentation, empathic product design, service co-creation, that marketing educators want to teach, short-term study abroad is perceived as a possibly more effective means to achieve that goal.

Third, beyond learning marketing and business concepts, short-term study abroad is perceived by students to be an effective pedagogical approach in helping them experience growth personally and interculturally. Compared to a regular quarter-long course, a short-term study abroad course achieves additional learning goals. This has long been the claim of all experiential learning and our study adds weight to the body of evidence that supports that claim.

Fourth, when designing short-term study abroad courses, if marketing educators have to make study abroad course design decisions prior to knowing the composition of the class, then they should err on the side of more daily free time rather than less. This design decision has the advantage of facilitating more perceived learning and increasing perceived student self-confidence than a program that is highly structured and planned.

Fifth, extrapolating from the previous implication, it may be likely that in any experiential learning-oriented course, students should be given the freedom to make more decisions regarding their learning, particularly in unfamiliar situations. As our Japan students demonstrated, even though they don't understand the language, if given free time, they will find ways to learn more. The resulting achievement will result in an increase in their self-confidence. 
Sixth, if marketing educators have access to student demographics and backgrounds prior to designing the short-term study abroad tour, then recognizing that bilingual students experience growth despite language barriers while non-bilingual students learn in a familiar language environment should be taken into account. Given a mix of these students, maybe roommate decisions can be made such that a bilingual student is paired with a non-bilingual student. Perhaps companies to be visited can be chosen so that students are exposed to U.S. companies in the foreign country in addition to local companies. Similarly, if the undergraduate-to-graduate student ratio skews more towards undergraduates then explicitly building in free time will help the undergraduates experience more growth without hurting the graduates.

Seventh, given a distribution of students with varying international traveling experience, perhaps alternating days of intense structure with days of freedom will end up helping both sets of students.

Finally and perhaps most importantly, our study helps marketing educators design targeted short-term study abroad tours based on student capabilities. For bilingual students, undergraduates, and more experienced travelers, a course with more flexibility is ideal. When going to a country with an unfamiliar language, the target audience is bilingual students and more experienced travelers. For non-bilingual students, traveling to a country where English is commonly used and where the program is highly structured is the best option. Similarly, less-experienced travelers will benefit from a highly structured program.

\section{Conclusions}

We identified five major gaps in the study abroad literature and designed a study to explicitly cover those gaps. Our findings contribute to the literature on marketing education by addressing a specific format of experiential learning, namely the short-term international study tour and demonstrating that it is an effective form of teaching that enhances overall perceived student growth. Future research could consider adding additional depth to the ways in which differential impact is assessed. A smaller subset of the perceptual measures can be administered to students not traveling abroad. Similarly, an ideal assessment would involve "before-and-after" measures that help tease out growth in a more nuanced manner. Future research can compare even more locations, perhaps across different continents to see if our results are generalizable. Future research could also study only graduate marketing students, as this is an extremely under-researched segment in the study abroad space. We studied only one type of short-term study abroad program. Future research could perhaps compare different types of short-term programs. Most previous research, including this paper, has used perceptual measures of most variables of interest. Future research that assesses study-abroad outcomes needs to start using actual measures of learning. Finally, future researchers could study the differential impact of short-term study abroad programs and long-term study abroad programs. Overall though, our research adds to the growing body of marketing study-abroad literature and provides valuable implications for all marketing educators.

\section{References}

Bacon, D. R. (2016). Reporting actual and perceived student learning in education research. Journal of Marketing Education, 38(1), 3-6. 
Clarke, I., III, Flaherty, T. B., Wright, N. D., McMillen, R. M. (2009). Student intercultural proficiency from study abroad programs. Journal of Marketing Education, 31, 173-181.

Cubillos, J. H., \& Ilvento, T. (2002). The impact of study abroad on students' self-efficacy perceptions. Foreign Language Annals, 45(4), 494-511.

Diamond, N., Koernig, S. K., \& Iqbal, Z. (2008). Uniting active and deep learning to teach problemsolving skills: strategic tools and the learning spiral. Journal of Marketing Education, 30(2), 116129.

Dow, D., \& Karunaratna, A. (2006). Developing a multidimensional instrument to measure psychic distance stimuli, Journal of International Business Studies, 37(5), 578-602.

Duke, C. R. (2000). Study abroad learning activities: A synthesis and comparison. Journal of Marketing Education, 22, 155-165.

Forsey, M. G., Broomhall, S., \& Davis, J. (2011). Broadening the mind? Australian student reflections on the experience of overseas study. Journal of Studies in International Education, 128-139.

Frontczak, N. T., \& Kelly, C. A. (2000). Experiential learning in marketing education [Special issue]. Journal of Marketing Education, 22(1), 3.

Gardner, P., Steglitz, I., \& Gross, L. (2009) Translating study abroad experiences for workplace competencies. Peer Review, 11(4) 19-22.

Gillan, K. J. (1996). A measure of global-mindedness at the University of Northern Colorado: An assessment of students, faculty, and administrators. Dissertation Abstracts International, 56(8), 3015A. (UMI No. 9544361)

Goel, L., De Jong, P., \& Schnusenberg, O. (2010). Toward a comprehensive framework of study abroad intentions and behaviors. Journal of Teaching in International Business, 21(4), 248-265.

Gordon, R. (2010). Going abroad: Traveling like an anthropologist. New York, NY: Paradigm.

Gullekson, N. L., Tucker, M. L., Coombs, G., Jr., \& Wright, S. B. (2011). Examining intercultural growth for business students in short-term study abroad programs: Too good to be true? Journal of Teaching in International Business, 22, 91-106.

Henthorne, T. L., Miller, M. M., \& Hudson, T. W. (2001). Building and positioning successful studyabroad programs. Journal of Teaching in International Business, 12(4), 49-62.

Hett, E. J. (1993). Development of an instrument to measure global-mindedness. Dissertation Abstracts International, 54(10), 3724. (UMI No. 9408210)

International Monetary Fund (2016). GDP based on PPP, share of world. Retrieved from https://www.imf.org/external/datamapper/PPPSH@WEO/OEMDC/ADVEC/WEOWORLD

Ismail, B., Morgan, M., \& Hayes, K. (2006). Effect of short study abroad course on student openness to diversity. Journal of Food Science Education, 1(1), 15-18.

Kang, B., \& Megehee, C. M. (2012). Advancing facilitators and deterrents theory of students' studyabroad decisions. Advances in Management, 7(12), 13.

Kaplin, D. (2013). Maximizing short-term study abroad programs offered by state comprehensive universities. Teacher-Scholar: The Journal of the State Comprehensive University, 5(1), 13-24.

Kavakas, D. (2013). Students as consumers: Identifying study abroad destination choice influences for marketing purposes. American College of Thessaloniki, 1-33.

Koernig, S. K. (2007). Planning, organizing, and conducting a 2-week study abroad trip for undergraduate students: Guidelines for first-time faculty. Journal of Marketing Education, 29(3), 210-217.

Kotler, P. T., \& Keller, K. L. (2015). Marketing Management. New York, NY: Pearson Publications.

Li, M., Olson, J. E., \& Frieze, I. H. (2013). Students' study abroad plans: The influence of motivational and personality factors. Frontiers: The Interdisciplinary Journal of Study Abroad, 22, 73-89.

Mills, L. H., Deviney, D., \& Ball, B. (2010). Short-term study abroad programs: A diversity of options. The Journal of Human Resource and Adult Learning, 6, 1-13.

Movassaghi, H., Unsal, F., \& Göçer, K. (2014). Study abroad decisions: Determinants \& perceived consequences. Journal of Higher Education Theory and Practice, 14(1), 69-80. 
Mozeleski, M. D. (2013). The cognitive and linguistic benefits of study abroad for all students. Murray State University Digital Archives (Paper 4). Retrieved from https://digitalcommons.murraystate.edu/lba-438/4/

Naffziger, D. W., Bott, J. P., \& Mueller, C. B. (2008). Factors influencing study abroad decisions among college of business students. International Business: Research, Teaching and Practice, 2(1), 39-52.

Naffziger, D. W., Bott, J. P., \& Mueller, C. B. (2010). Study abroad: Validating the factor analysis of student choices. International Business: Research, Teaching and Practice, 4(1), 72-81.

Nunan, P. (2006). An exploration of the long term effects of student exchange experiences. In Proceedings of the IDP Australian International Education Conference (pp. 1-10). Retrieved from https://www.voced.edu.au/content/ngv\%3A16906

Oldford, J. (2010). Impact of short-term study abroad on MBA students (MA Thesis). Retrieved from http://ecommons.luc.edu/cgi/viewcontent.cgi?article=1491\&context=luc_theses

Olson, C. L., \& Kroeger, K. R. (2001). Global competency and intercultural sensitivity. Journal of Studies in International Education, 5(2), 116-137.

Omachinski, K. M. (2013). Communication and cultural implications of short-term study-abroad experiences of engineering students. Connexions: International Professional Communication, 1(2), 43-77.

Institute of International Education. (2015). Open Doors: Fast facts. Retrieved from http://www.iie.org/Research-and-Publications/Open-Doors/Data/Fast-Facts\#.V4-11DkrI3g

Institute of International Education. (2018). Open Doors: Fast facts. Retrieved from https://www.iie.org/Research-and-Insights/Open-Doors

Pascarella, E. T., Edison, M. Nora, A., Hagedorn, L. S., \& Terenzini, P. T. (1996). Influences on student's openness to diversity and challenges in the first year of college. Journal of Higher Education, 67(2), 179.

Pike, G. R. (2002). The differential effects of on- and off-campus living arrangements on students' openness to diversity. National Association of Student Personnel Administrators Journal, 39(4), 283299.

Quraeshi, Z. A., Luqmani, M., \& Veeck, A. (2012). Advancing the participation of business students in study abroad programs. Global Journal of Management and Business Research, 12(11), 81-91.

Sachau, D., Brasher, N., \& Fee, S. (2010). Three models for short-term study abroad. Journal of Management Education, 34(5), 645-670.

Tamas, A. (2014). Advantages of study abroad from the students' perspective. International Journal of Teaching and Education, 2(4), 67-88.

Van Doren, D., \& Corrigan, H. B. (2008). Designing a marketing course with field site visits. Journal of Marketing Education, 30(3), 189-206.

Woolf, M. (2007). Impossible things before breakfast: Myths in education abroad. Journal of Studies in International Education, 11(4), 496-509.

Zamastil-Vondrova, K. (2005). Good faith or hard data? Justifying short-term programs. International Educator, 14, 44-49.

\section{Appendix: Measurement Scales}

Self Confidence ( 1 item; measured on 7 point Likert-like scale; anchors " 1 = Significantly less than a traditional 10 week class, $7=$ Significantly more than a traditional 10 week class")

1. Overall, compared to a traditional 10 week class, please choose the option that best represents your level of confidence after the last Study Abroad International Business Seminar that you participated in? 
Efficacy (Hett, 1993; 5 items; measured on a 7 point Likert-like scale; anchors "1 = Strongly disagree, 7 = Strongly agree")

1. Really, there is nothing I can do about the problems of the world. (Reverse)

2. Generally, an individual's actions are too small to have a significant effect on the ecosystem. (Reverse)

3. It is very important to me to choose a career in which I can have a positive effect on quality of life for future generations.

4. I think my behavior can impact people in other countries.

5. I am able to affect what happens on a global level by what I do in my own community.

Sense of Responsibility (Hett, 1993: 7 items; measured on a 7 point Likert-like scale; anchors "1 = Strongly disagree, 7 = Strongly agree")

1. I feel an obligation to speak out when I see our government doing something I consider wrong.

2. When I hear that thousands of people are starving in an African country, I feel very frustrated.

3. When I see the conditions some people in the world live under, I feel a responsibility to do something about it.

4. The fact that a flood can kill 50,000 people in Bangladesh is very depressing to me.

5. I feel very concerned about the lives of people who live in politically repressive regimes.

6. I sometimes try to imagine how a person who is always hungry must feel.

7. Americans have a moral obligation to share their wealth with the less fortunate peoples of the world.

Level of Learning ( 1 item; measured on 7 point Likert-like scale; anchors " 1 = Significantly less than a traditional 10 week class, $7=$ Significantly more than a traditional 10 week class")

1. Overall, compared to a traditional 10 week class, please choose the option that best represents your level of learning from the last Study Abroad International Business Seminar that you participated in?

Applicability to Career Goals ( 1 item; measured on 7 point Likert-like scale; anchors " 1 = Very inapplicable, 7 = Very applicable")

2. In your opinion, how applicable has the last Study Abroad International Business Seminar been to your career goals?

Cultural Pluralism (Hett, 1993; 8 items; measured on a 7 point Likert-like scale; anchors "1 = Strongly disagree, 7 = Strongly agree")

1. I generally find it stimulating to spend an evening talking with people from another culture.

2. The United States is enriched by the fact that it is comprised of many people from different cultures and countries. 
3. Americans can learn something of value from all different cultures.

4. I enjoy trying to understand people's behavior in the context of their culture.

5. My opinions about national policies are based on how those policies might affect the rest of the world as well as the United States.

6. It is important that American universities and colleges provide programs designed to promote understanding among students of different ethnic and cultural backgrounds.

7. It is important that we educate people to understand the impact that current policies might have on future generations.

8. I have very little in common with people in underdeveloped nations. (Reverse)

Openness to Diversity (Pascarella, et al, 1996; 8 items; measured on a 7 point Likert-like scale; anchors " $1=$ Strongly disagree, $7=$ Strongly agree")

1. I enjoy having discussions with people whose ideas and values are different from my own.

2. The real value of a college education lies in being introduced to different values.

3. I enjoy talking with people who have values different from mine because it helps me understand myself and my values better.

4. Learning about people from different cultures is a very important part of my college education.

5. I enjoy taking courses that challenge my beliefs and values.

6. The courses I enjoy the most are those that make me think about things from a different perspective.

7. Contact with individuals whose background (e.g., race, national origin, sexual orientation) is different from my own is an essential part of my college education.

8. I enjoy courses that are intellectually challenging.

Intercultural Communication (Olson \& Kroger, 2001; 11 items; measured on a 7 point Likertlike scale; anchors " 1 = Strongly disagree, 7 = Strongly agree")

1. I feel uncomfortable when I am with people who are speaking a language I do not know.

2. I try to learn about people from other cultures so that we can work and socialize together.

3. I incorporate the attractive aspects of other cultures into my way of doing things.

4. I have learned how to produce work with people from other places in the globe.

5. I feel self-confident and comfortable socializing with people from other cultures.

6. I have lived abroad and experienced intense interaction with a variety of people from this other culture.

7. I have long-term friendships with several people from other cultures.

8. I am currently engaged in professional work with at least three people in other countries.

9. I have the ability to deal flexibly with and adjust to new people, places, and situations.

10. I have the ability to psychologically put myself into another person's shoes.

11. I can act as a cultural mediator and serve as a bridge between people of different cultures. 